\title{
Menuju Gereja Apostolik Transformatif
}

\author{
Gernaida K. R. Pakpahan ${ }^{1 *}$, Frans Pantan², Epafras Djohan Handojo ${ }^{3}$ \\ 1,2,3Sekolah Tinggi Teologi Bethel Indonesia, Jakarta \\ *gernaidapakpahan@sttbi.ac.id
}

\begin{tabular}{l} 
Article History \\
Received: \\
01 November 2020 \\
Revised: \\
26 Mei 2021 \\
Accepted: \\
30 Mei 2021 \\
\hline \\
Keywords \\
(Kata kunci): \\
apostolic church; \\
Charismatic church; \\
discipleship; \\
Church leader; \\
Gereja Bethel \\
Indonesia; \\
transformative \\
church; \\
gereja apostolik; \\
gereja Kharismatik; \\
gereja \\
transformatif; \\
pemuridan \\
D0l: \\
http://dx.doi.org/10. \\
33991/epigraphe.v5i1.125 \\
\\
\end{tabular}

\begin{abstract}
Peter Wagner, as an experts on church growth, stated that the Apostolic church is a church that is experiencing rapid growth. This claim is made because many Apostolic churches have been built around the world. The church continued the spirit of the apostles at the time of the early church's birth. However, it is important to conduct an in-depth study regarding the realization in the field; whether a thriving Apostolic church is carrying out God's mission or the personal ambition of a charismatic church leader. This study analyzes how the church which is said to be an Apostolic church runs its organization, so that it experiences significant growth. The research method used is descriptive qualitative. The researcher tries to explore the phenomena and data obtained through respondents about the transformative apostolic church that was developed in the ministry of the Indonesian Bethel Church of Gatot Subroto. In conclusion, GBI Gatot Subroto is a transformative apostolic church, because of several things, such as: a visionary church, senior pastors or mentor pastors as apostolic leaders, divine authority and the work of the Holy Spirit have an impact, the church as a center for leadership training and discipleship across generations, implements apostolic ministry followed by other gifts/services, prioritizing mission, and focusing on the Kingdom of God.
\end{abstract}

\section{Abstrak}

Peter Wagner, sebagai salah satu ahli pertumbuhan gereja, menyatakan bahwa gereja Apostolik adalah gereja yang mengalami pertumbuhan secara pesat. Klaim ini disampaikan karena banyak-nya terbangun gereja-gereja beraliran Apostolik di seluruh dunia. Gereja tersebut melanjutkan semangat para rasul pada masa lahirnya gereja mula-mula. Namun, penting untuk dilakukan kajian mendalam terkait realisasi di lapangan; apakah gereja Apostolik yang berkembang menja-lankan misi Allah atau ambisi pribadi dari pemimpin gereja yang berkharismatik. Penelitian ini menganalisis bagaimana gereja yang dikatakan sebagai gereja Apostolik menjalankan organisasinya, sehingga mengalami pertumbuhan yang signifikan. Metode penelitian yang digunakan adalah kualitatif deskriptif. Peneliti berusaha mengeksplorasi fenomena dan data-data yang diperoleh melalui responden tentang gereja apostolik transformatif yang dikembangkan dalam pelayanan Gereja Bethel Indonesia Gatot Subroto. Kesimpu-lannya, GBI Gatot Subroto adalah gereja apostolik transformatif, karena beberapa hal, seperti: gereja yang visioner, gembala senior atau gembala pembina sebagai pemimpin kerasulan, otoritas Ilahi dan pekerjaan Roh Kudus berdampak, gereja sebagai pusat pelatihan kepemimpinan dan pemuridan lintas generasi, menerapkan jawatan rasuli diikuti karunia-karunia/jawatan lainnya, memprioritaskan misi, dan berfokus pada Kerajaan Allah. 


\section{Pendahuluan}

Kaum Pentakosta mayakini bahwa kehadiran gereja di bumi ini terkait atau berhubungan erat dengan kehadiran Roh Kudus. Pemahaman seperti itu sebenarnya ingin menegaskan bahwa pada dasarnya gereja lahir, eksis, dan berkembang di dunia nyata ini karena berkat kuasa Allah dan kehendak-Nya. Dengan demikian, berdirinya gereja sama sekali bukan karena kehendak atau keputusan manusia. Peran dan fungsi manusia hanyalah sebagai alat (tools) yang Allah berkenan pakai untuk mengelola gereja-Nya menurut kehendak-Nya di dunia konkret ini. ${ }^{1}$

Kegerakan kebangunan Rohani terjadi secara spektakuler setelah murid-murid Yesus mengalami pristiwa Pentakosta (Kis. 2:14-40). Umat yang hadir dalam kebaktian kebangunan rohani akbar tersebut bertanya apa yang harus mereka lakukan. Para rasul menjawab dengan jelas, bahwa mereka harus bertobat, dibaptis, dan menerima Roh Kudus (Kis. 2:38). Mereka yang menerima Yesus Kristus memberi diri dibaptis, sehingga dosanya dihapus, dan mereka pun menerima rahmat pengudusan, dan karenanya pada saat itu baptisan menandai awal perjalanan menuju menjadi anggota gereja. Peristiwa ini tampak jelas bahwa terdapat hubungan antara pemberitaan Injil dan pertobatan, yang mengarah pada baptisan dan masuknya seseorang menjadi anggota gereja. Terkait dengan proses tersebut, tampak secara signifikan peran para rasul melalui pemberitaan atau pewartaan berita keselamatan yang berpusat hanya pada Yesus Kristus. Bahkan para rasul dengan tegas memberitakan bahwa di bawah kolong langit tidak ada satu nama yang di dalamnya seseorang dapat diselamatkan selain di dalam nama Tuhan Yesus Kristus (Kis. 4:12).

Pada umumnya kelompok gereja aliran Pentakosta memahami gereja mula-mula (awal) yang dinarasikan dalam kitab Kisah Para Rasul sebagai model gereja apostolik. ${ }^{2}$ Apostolik sendiri adalah ciri gereja yang menuntut penyampaian atau pewartaan injil kepada manusia dengan bahasa yang dapat dimengerti sesuai dengan kebutuhan dan keadaan zaman. ${ }^{3}$ Kegiatan pergerakannya dimulai dari "upper room experience," di kota Yerusalem hingga Penyebaran Injil yang dibawa oleh para rasul ke seluruh dunia. Meskipun dalam Kisah Para Rasul yang menonjol adalah Petrus dan Paulus, tetapi keduanya dianggap sebagai perwakilan dari rasulrasul yang lain. Petrus mewakili pemberitaan Injil kepada orang-orang Yahudi, sedangkan Paulus kepada orang non-Yahudi (Gentile). Yang penting dipahami bahwa para murid yang mengalami kepenuhan Roh Kudus menerima kelengkapan otoritas ilahi atau kuasa ilahi dalam melaksanakan tugas penjangkauan banyak orang menjadi pengikut Yesus Kristus sebagai Tuhan dan Juruselamat satu-satunya.

Bahkan, sebelum Pentakosta Yesus Kristus sudah berkata bahwa turunnya Roh Kudus akan membuat para rasul menjadi saksi-Nya sampai ke ujung bumi. Para rasul dan murid yang masuk dalam bagian 120 orang yang setia berdoa untuk menanti Pencurahan Roh Kudus dipenuhi Roh Kudus sehingga memiliki kemampuan luar biasa untuk berbicara dalam bahasa yang berbedabeda, yakni bahasa yang digunakan atau dipakai oleh masyarakat dunia (xenolalia). Pengalaman itu ingin menegaskan bahwa sejak lahirnya gereja sudah memiliki ciri universal dan misioner, karena adanya kuasa Roh Kudus yang memampukan para rasul untuk berbicara dalam banyak

\footnotetext{
${ }^{1}$ Peter Wagner, Changing Church: How God Is Leading His Church into The Future (California: Ventura, 2014).

2 John Christopher Thomas, Toward a Pentecostal Ecclesiology: The Church and the Fivefold Gospel (Cleveland, Tennessee: CPT Press, n.d.).

${ }^{3}$ FX Wibowo Ardhi, Arti Gereja (Yogyakarta: Kanisius, 1993).
} 
bahasa. Dikatakan universal, karena speak in tounge yang terjadi di Yerusalem dihadiri oleh orang-orang Yahudi dari seluruh dunia yang sedang merayakan hari Pentakosta Yahudi bersama. Peristiwa ini adalah salah satu mukjizat yang luar biasa di mana terjadi penuaian jiwa bagi Kristus secara besar-besaran untuk pertama kalinya.

Selain apostolik, gereja mula-mula juga erat kaitannya dengan semangat dan tindakan transformatif. Jemaat mula-mula saling membantu satu dengan lain, yang kaya dan yang miskin tidak terdapat jurang pemisah. ${ }^{4}$ Terdapat persekutuan-persekutuan dan pengajaran dengan para rasul. ${ }^{5}$ Itu sebabnya, pelayanan pengajaran dan Firman Tuhan dengan memperhatikan para janda mulai dipisah. Itu sebabnya, para rasul segera menyuruh jemaat memilih tujuh orang yang cakap untuk memegang pelayanan ini. Indicator yang diberikan adalah mereka yang terkenal baik, penuh Roh Kudus dan hikmat untuk menangani pelayanan meja (Kis. 6:1-7). Rasul-rasul memandang pelayanan Firman Tuhan sebagai hal yang penting dalam jemaat untuk pertumbuhan jemaat secara rohani. ${ }^{6}$

Pembahasan mengenai gereja yang Apostolik pernah diteliti oleh Gardius Hardian yang menyoroti bagaimana gereja mesti melakukan networking. ${ }^{7}$ Networking yang dimaksud adalah bagaimana teknologi yang pesat berkembang hari-hari ini harus dimanfaatkan untuk berhubungan dengan masyarakat secara luas. Dalam kesimpulannya, Hardian menyatakan bahwa gereja sebagai komunio, paguyuban, dan persekutuannya mesti dikemukakan dan dihidupi terlebih dahulu baru kemudian aspek hierarki, institusi, dan yuridisnya. Teladan dari para rasul dan Gereja perdana kiranya menjadi pegangan agar nyala api komunio tetap menyala dalam iman dan hidup menggerejaseperti di dalam Kisah Para Rasul (Bdk. Kis 2:42-47). Sedangkan terkait dengan gereja transformative, Henry Simamora yang membahas bagaimana gereja melakukan gerakan misi transformasi. Dalam kesimpulannya, Simamora menyatakan bahwa gerakan transformasi harus bersifat universal bagi seluruh orang percaya dan yang belum percaya. ${ }^{8}$ Sedangkan Dalensang lebih menekankan transformasi khusus kepada orang miskin. ${ }^{9}$

Dari beberapa penelitian di atas, pembahasan dari gereja yang apostolik transformatif hanya kepada konsep dan prinsip yang harus dilakukan oleh gereja. Itu sebabnya, yang menjadi kebaruan dari penelitian ini adalah bagaimana implementasi gereja Apostolik yang transformatif dilihat dari seluruh aspek kehidupan manusia dilakukan oleh Gereja Bethel Indonesia Gatot Subroto.

\footnotetext{
${ }^{4}$ Yushak Soesilo, "Pentakostalisme Dan Aksi Sosial: Analisis Struktural Kisah Para Rasul 2 : 41-47," DUNAMIS: Jurnal Teologi dan Pendidikan Kristiani 2, no. 2 (2018): 136-151, http://sttintheos.ac.id/ejournal/index.php/dunamis/article/view/172/134; Johannis Siahaya and Harls Evan R Siahaan, "Menggagas Hospitalitas Pentakostal: Membaca Ulang Kisah Para Rasul 2: 44-47 Di Masa Pandemi," DUNAMIS: Jurnal Teologi dan Pendidikan Kristiani 5, no. 2 (2021): 426-439.

5 Andreas Sese Sunarko, "Implementasi Cara Hidup Jemaat Mula-Mula Dalam Kisah Para Rasul 2: 41-47 Bagi Pertumbuhan Gereja Masa Kini,” KHARISMATA: Jurnal Teologi Pantekosta 2, no. 2 (2020): 127-140.

${ }^{6}$ Widi Prasetyo, "Rekrutmen Pelayan Yang Ideal Menurut Kisah Para Rasul 6:3," Kerusso 1, no. 1 (2016): $57-64$.

${ }^{7}$ Gerardus Hadian Panamokta, "Menuju Gereja Terjaring (Networked Church)," Jurnal Teologi 7, no. 1 (2018): 9-30

${ }^{8}$ Ridwan Henry Simamora, "Gereja Dan Transformasi Kristen Suatu Tinjauan Kritis Terhadap Misi Gerakan Transformasi," Missio Ecclesiae 03, no. 04 (2013): 84-109.

${ }^{9}$ Remelia F Dalensang, "Menjadi Gereja Yang Transformatif Bagi Kaum Miskin 'Dari Mana Dan Ke Mana Arah Pembangunan Jemaat?"” 7 (2018): 51-61.
} 


\section{Metode}

Dalam sebuah penelitian ilmiah, data merupakan aspek yang sangat penting dan tidak boleh dimanipulasi. Karena berdasarkan data tersebut, peneliti dapat menganalisis hasil dari penelitian tersebut. Dalam penelitian ini, data diperoleh dari para pimpinan rayon di GBI Gatot Subroto, para tokoh gereja di luar gereja Gatot Subroto, yakni di level aras nasional, dan juga para teolog di luar negeri yang bergerak di dalam pelayanan gerakan gereja apostolik transformatif. Sesuai dengan karakteristik data yang diperlukan dalam penelitian ini, maka teknik pengumpulan data yang dilakukan adalah melalui observasi dan wawancara.

Pada umumnya observasi dipahami sebagai suatu aktivitas pengamatan terhadap sebuah objek yang diamati secara langsung dengan suatu pengamatan yang mendetail dalam rangka menemukan dan mendapatkan informasi mengenai objek yang diamati. Itulah sebabnya kegiatan observasi harus tersistematis serta dapat dipertanggungjawabkan kebenarannya, termasuk proses kerjanya. Di samping itu, objek yang diamati dalam kegiatan observasi harus konkret dan diamati secara langsung. Terkait dengan itu, peneliti adalah bagian integral dari GBI Gatot Subroto yang sudah melayani dan terlibat dalam kepemimpinan di GBI Gatot Subroto sejak awal sampai sekarang.

Sementara wawancara adalah sebuah proses yang biasa dilakukan di dalam penelitian untuk memperoleh keterangan terkait dengan data-data atau informasi yang dibutuhkan dalam sebuah penelitian ilmiah. Wawancara dilakukan dengan cara melakukan tanya jawab secara tatap muka maupun tatap maya lewat Whatsapp Call, Zoom, Google Meet, dan media online meeting lainnya. dengan responden sebagai narasumber. Untuk menghindari bias dalam proses wawancara, maka pada umumnya wawancara dilakukan dengan menggunakan pedoman atau panduan wawancara. Dalam penelitian ini, peneliti mencatat semua jawaban dari responden sebagaimana adanya. Karena itu, jenis wawancara yang digunakan dalam penelitian ini adalah wawancara terstruktur. Maksudnya, dalam melakukan wawancara peneliti sudah menyiapkan instrumen penelitian berupa pertanyaan-pertanyaan tertulis. Dalam penelitian ini, wawancara dilakukan dengan para pimpinan rayon di lingkungan GBI Gatot Subroto, tokoh gereja aras nasional, dan beberapa tokoh gereja serta pemimpin lembaga pelayanan kristiani internasional.

\section{Hasil Dan Pembahasan}

\section{Kajian Teologi tentang Gereja Apostolik Transformatif}

Berbicara mengenai eksistensi gereja di dunia, tidak dapat dipisahkan dari konsep kerajaan Allah yang hendak didirikan Allah di dunia. Sebab kerajaan Allah adalah Tuhan Allah memerintah sebagai Raja yang berdaulat atas segala sesuatu. Itu sebabnya, pelayanan Kerajaan Allah di bumi memiliki tujuan untuk transformasi kehidupan antara lain: merekonsiliasi manusia dengan sang Raja, memulihkan keadaan manusia kepada gambar Allah (Image of God) ${ }^{10}$, dan mengubah keadaan manusia untuk mempersiapkan pemerintahan dunia baru dalam kerajaan 1000 tahun menuju pada kekekalan. ${ }^{11}$

Dipercayai bahwa gereja adalah komunitas dari sang raja, tubuh Kristus terlihat dan ada sebagai kehadiran dari kerajaan Allah di bumi (Ef. 1:22-23). Di sisi lain, iblis beroposisi mela-

\footnotetext{
${ }^{10}$ Anggi Maringan Hasiholan, "Studi Komparatif Terhadap Pemahaman Teologi Reformed Dengan Pemahaman Teologi Pentakosta Tentang Natur Manusia,” Pneumata 1, no. 1 (2020): 54-71.

${ }^{11}$ Chris Sugden dan Vinay Samuel, Mission as Transformation: A Theology of the Whole Gospel (Eugene: Wipf and Stock Publishers, 2009).
} 
wan kerajaan Allah di dalam konflik kekerasan sejak kejatuhan manusia sampai kedatangan Kristus sehingga peperangan rohani terjadi antara kerajaan Allah dan kerajaan kegelapan (Mat. 12:28, Kol. 1:12-13). Oleh karenanya, Kerajaan Allah harus memberi dampak pada setiap kebutuhan manusia baik fisikal, budaya, sosial, spiritual, intellectual, dan kepenuhan emosi dari kehidupan manusia (Mat. 25:31-40). Kerajaan Allah dan masa yang akan datang, Yesus Kristus akan kembali dan memulihkan segala sesuatu di dalam Dia (Kol. 1:19-20, Yoh. 14:3). Di dalam pengajaran Yesus sangat jelas bahawa Dia memproklamasikan bahawa kerajaan Allah telah datang dan kerajaan kekal yang akan ada. (Luk. 11:20, 12:32, Mat. 13:36-43). ${ }^{12}$

Gereja apostolik adalah gereja yang didasari pada pemberdayaan Roh Kudus kepada para Rasul, yang dilanjutkan oleh para penerusnya. Roh Kudus memakai para Rasul untuk menyampaikan kabar Baik kepada orang yang belum percaya kepada Kristus melalui demontrasi Injil dan keteladanan hidup. ${ }^{13}$ Secara praktis, kehidupan kekristenan termanifestasi dari kehidupan baru. Kekristenan naik jauh di atas semua agama lain dalam teori dan praktik kebajikan dan kesalehan. Hal ini menetapkan standar tertinggi kasih kepada Tuhan dan kepada manusia; dan ini bukan hanya sebagai abstrak, tetapi sebagai fakta yang hidup dalam pribadi Yesus Kristus, yang kehidupan dan teladan memiliki lebih banyak kekuatan dan pengaruh daripada semua prinsip dan ajaran orang bijak dan legislator. ${ }^{14}$

Buah dari apostolik itu melahirkan gereja yang transformatif. Dimulai dari individu yang kehidupan sehari-harinya semakin dipersatukan dengan Kristus. Hidup dalam kesalehan dikedepankan, moral dalam kehidupan masyarakat menjadi value yang harus dimiliki orang percaya, keterlibatan perempuan dalam pelayanan dan adanya kesetaraan dengan pria yang selama ini terabaikan, dan kebebasan dari dosa. Selanjutnya, transformasi dalam keluar-ga. ${ }^{15}$ Ini menghapus poligami, dan menjadikan monogami sebagai bentuk pernikahan yang tepat. Kekristenan mengutuk pergundikan dengan segala bentuk ketidaksucian dan kenajisan. Hal ini menyajikan tugas bersama suami dan istri, dan orang tua dan anak-anak, dalam cahaya sejati mereka, dan menunjukkan perkawinan sebagai persamaan tentang persatuan Kristus dengan mempelai wanita, gereja; dengan demikian memberikan kepadanya karakter suci. Demikian juga Kekristenan masuk ke dalam ranah kehidupan social masyarakat. Kekristenan dengan kebaji-kannya yang seperti ragi memasuki seluruh kehidupan sipil dan sosial suatu bangsa, dan me-mimpinnya di jalan kemajuan di semua peradaban sejati. Kekristenan mereformasi hubungan internasional dengan meruntuhkan tembok pemisah prasangka dan kebencian di antara berbagai bangsa dan ras. Itu bersatu dalam persekutuan persaudaraan dan harmoni di sekitar meja per-sekutuan yang sama bahkan orang-orang Yahudi dan non-Yahudi, yang dulu sangat terpisah dan bermusuhan. Semangat Kekristenan, benar-benar universal, muncul di atas semua perbedaan nasional. ${ }^{16}$

\section{Gereja Apostolik digerakan oleh Roh Kudus}

Sangat diyakini sungguh-sungguh, bahwa karya misi gereja pertama adalah merupakan karya Roh Kudus. Walaupun benar memang bahwa pada saat yang bersamaan juga tetap membutuh-

\footnotetext{
${ }^{12}$ Coombs Barney, Apostles Today - Christ's Love-Gift to the Church (England: Sovereign World Ltd, 1996).

${ }^{13}$ Cornelius Pulung, "Gereja Yang Satu, Kudus Dan Apostolik Dalam Gereja Katolik," BINUS University (2020): 1-20.

${ }^{14}$ Philip Schaff, History of the Christian Church, Volume I: Apostolic Christianity. A.D. 1-100 (USA: Christian Classics Ethereal Library, 1882).

${ }^{15}$ Wayne Grudem, The Biblical Foundations on Manhood and Womanhood: The Myth of Mutual Submission As An Interpretation Of Ephesians 5:21 (Wheaton, Illinois: Crossway Books, 2002).

${ }^{16}$ Schaff, History of the Christian Church, Volume I: Apostolic Christianity. A.D. 1-100.
} 
kan kerja sama manusia. Peristiwa ini justru bertolak belakang dengan peristiwa pembangunan menara Babel; ketika orang ingin membangun jalan menuju ke surga dengan tangan mereka namun berakhir dengan kehancuran kapasitas untuk saling memahami. Berbeda dengan peristiwa Pentakosta, di mana Roh Kudus efektif menyatukan dan mengubah kekacauan (confusion) menjadi persekutuan (communion). Karena itu, faktor unity (persatuan, kesatuan) dari umat merupakan salah satu kondisi yang Allah kehendaki untuk Roh Kudus bekerja secara luar biasa melalui umat-Nya. ${ }^{17}$

Urgensi atau pentingnya pengurapan Roh Kudus rupanya bukan hanya bagi para rasul/ murid dan orang percaya yang membutuhkan pengurapan Roh Kudus melainkan termasuk juga Yesus Kristus itu sendiri. Fakta itu dijelaskan oleh rasul Petrus di dalam Kisah Para Rasul 10:38, di mana disebutkan secara jelas bahwa sebelum Yesus Kristus berkeliling berbuat baik dan menyembuhkan semua orang yang dikuasai Iblis, maka terlebih dahulu Ia mendapat pengurapan dari Allah Bapa dengan Roh Kudus sehingga dengan kuat kuasa Roh Kudus itulah yang menjadikan Yesus Kristus efektif melayani di seluruh tanah Yudea dan Yerusalem (lih. ay. 38). Jadi, apa yang dicontohkan oleh Yesus Kristus dalam konteks pelaksanaan panggilan dan tugas pelayanan-Nya kepada umat manusia adalah hal yang sangat esensial untuk dibudayakan dalam pelayanan gerejawi. Pemahaman inilah yang menjadi salah satu prinsip fundamental dari pelayanan gereja apostolik. ${ }^{18}$

Secara garis besar, dapat digambarkan pengalaman-pengalaman yang terjadi pada gereja mula-mula, atau yang biasa juga dikenal dengan "Gereja Kisah Rasul”, ada hal-hal menonjol yang terjadi, antara lain: multiplikasi jiwa-jiwa melalui khotbah perdana rasul Petrus, pengajaran rasul-rasul disambut oleh umat dengan antusias, tanda dan mujizat (sign and wonders) menyertai pelayanan para rasul dan orang percaya, orang percaya gemar membaca dan mempraktikkan firman Allah, senang bersekutu untuk berdoa-memuji- menyembah di rumah-rumah, memiliki kepedulian sosial yang tinggi, bahkan kehidupan mereka disukai semua orang sehingga mengakibatkan jumlah orang percaya terus bertambah secara signifikan dari waktu ke waktu. ${ }^{19}$

\section{Implementasi Gereja Apostolik yang Transformatif}

Dari paparan diata, maka terdapat beberapa tindakan implementatif yang dapat semestinya ada dalam gereja yang Apostolik transformative. Pertama, Gereja yang visioner. Setelah pencurahan Roh kudus, visi dari para rasul dan orang percaya adalah melaksanakan Amanat Agung (Mat. 28:19-20). ${ }^{20}$ Ini adalah visi yang akhirnya tergenapi ketika orang percaya dipenuhki oleh Roh Kudus. Gereja yang apostolik transformatif mesti memiliki visi ini yang dapat terimplementasi secara menyeluruh. Kedua, Gereja di mana gembala senior bertindak sebagai pemimpin kerasulan. Pelayan di bawah rasul pada gereja mula-mula amatlah banyak, karena ada pemuridan dan pemokusan dari tanggungj awab rasul. Rasul tidak lagi memikirkan pelayanan meja, tetapi

\footnotetext{
${ }^{17}$ Cannistraci David, Karunia Rasul: Sebuah Pandangan Alkitabiah Mengenai Jawatan Rasul Dan Bagaimana Tuhan Sedang Menggunakannya Untuk Memberkati Gereja-Nya Dewasa Ini (Jakarta: Nafiri Gabriel, 1997).

${ }^{18}$ Choudhrie Victor, Greet the Ekklesia! The Church in Your House, Kindle edi. (Power through love, 2012).

${ }^{19}$ Willem A Van Gemeren, Penginterpretasian Kitab Para Nabi (Surabaya: Momentum, 2007).

${ }^{20}$ Susanto Dwiraharjo, "Kajian Eksegetikal Amanat Agung Menurut Matius 28: 18-20," Jurnal Teologi Gracia Deo 1, no. 2 (2019): 56-73, http://sttbaptisjkt.ac.id/e-journal/index.php/graciadeo; Fransiskus Irwan Widjaja, Daniel Ginting, and Sabar Manahan Hutagalung, "Teologi Misi Sebagai Teologi Amanat Agung," THRONOS: Jurnal Teologi Kristen 1, no. 1 (2019): 17-24.
} 
fokus kepada pelayanan altar. Namun, pun demikian, para Rasul juga memiliki peran untuk memiliki siapa yang tepat menduduki posisi itu, dan mengontrol selama pengerjaanya.

Ketiga, gereja di mana ada otoritas ilahi dan manifestasi karya Roh Kudus yang berdampak. Kehidupan ilahi dalam gereja tidak dihindarkan karena dianggap tidak sesuai dengan liturgi yang telah gereja bakukan. Manifestasi karya Roh kudus harus tetap eksis meskipun harus tetap disertai dengan keteraturan. Keempat, gereja sebagai pusat pelatihan kepemimpinan dan pemuridan lintas generasi. Kelima, gereja yang menerapkan jawatan rasuli. Keenam, gereja dengan prioritas misi dan penginjilan. Tentu hal ini terkait erat dengan makna "rasul" sebagai seseorang yang diutus untuk misi tertentu. Maka gereja apostolik transformative mesti mengutus seluruh jemaatnya untuk melakukan penginjilan. Ketujuh, gereja yang berfokus kepada Kerajaan Allah dan persiapan menuju kekekalan. Kedelapan, gereja di mana Penyembahan menjadi gaya hidup. Kesembilan, gereja dengan tingkat gairah doa yang berkobar-kobar. Kesepuluh, gereja yang memiliki panggilan pelayanan Transformasi. Kesebelas, gereja dengan pengelolaan keuangan yang alkitabiah.

\section{Gereja Apostolik Transformatif: Sebuah Refleksi GBI Gatot Subroto}

Setelah melakukan observasi dan wawancara kepada tokoh-tokoh Gereja Bethel Indonesia (GBI) Gatot Subroto, maka didapatkan fakta, bahwa GBI Gatot Subroto telah memulai kegerakan apostolik transformatif untuk jangkauan Indonesia sebagai bangsa yang majemuk dengan multi kultur, ras, golongan, dan agama (nasional), dan juga bangsa-bangsa lain (international). Itu sebabnya, terdapat tujuh bidang yang menjadi fokus pelayanan yang ditempuh GBI Gatot Subroto.

Pertama, Art media entertainment. GBI Gatot Subroto memberi ruang yang luas bagi warga jemaat terutama generasi muda untuk bergerak dalam kegiatan seni, musik, dan pelayanan media. Di setiap rayon memiliki keunggulan-keunggulan di bidang-bidang tertentu untuk memberkati generasi muda, sekolah-sekolah dan gereja-gereja. Misalnya, pelayanan pelayanan media dari GBI Gatot Subroto melalui Healing Movement Ministry yang tersebar di stasiunstasiun TV nasional dan juga sampai ke bangsa-bangsa berbahasa Inggris, bahkan yang berbahasa Rusia di negara- negara bekas Uni Sovyet. Dalam musik maka lagu-lagu yang diciptakan oleh para worshipper di GBI Gatot Subroto sejak 30 tahun telah menjadi berkat dan mentransformasi banyak gereja yang berbahasa Inggris, gereja-gereja berbahasa Mandarin di Asia, berbahasa Melayu di Sabah, Sarawak, Malaysia, bahasa Vietnam, Korea, Jepang dan lain-lain. Bahkan lagu-lagu GBI Gatot Subroto diterjemahkan, direkam ulang dan dinyanyikan di berbagai bangsa. Tindakan ini dilakukan sebagai suatu implementasi akan pemulihan Pondok Daud. ${ }^{21}$ Apostolik yang dilakukan menggunakan media telah membuat point 1, 6 dan 8 dari implementasi gereja apostolik transformatif dapat dilakukan.

Kedua, Business and Marketplace. Pelayanan di dunia usaha melalui UMKM, seperti micro enterprise, seminar-seminar dan fellowship mingguan pada hari Jumat yang diadakan di kantor-kantor yang tersebar di ibukota dan beberapa ibukota provinsi. Business Office Ministry (BOM) dari GBI Gatot Subroto telah menjangkau dunia profesi dan pebisnis di kantor dan pabrik. Adapun penekanan yang dikemukakan adalah pentingnya pemahaman nilai-nilai kerajaan Allah dalam dunia business/kerja. Banyak para pengusaha di dalam jemaat GBI Gatot

${ }^{21}$ Daniel Tomberlin, Encountering God at The Altar, Pentecostal Sacraments (Cleveland, Tennessee: Thomas Nelson, 2015). 
Subroto terlibat secara aktif di dalam penginjilan dan penerapan prinsip-prinsip pengelolaan harta bangsa- bangsa. Dalam banyak hal pelayanan ini terlibat untuk menabur bagi pelayanan misi transformasi dan penanaman gereja di berbagai tempat. Tindakan ini dilakukan supaya amanat agung tetap dilaksanakan dalam segala aspek kehidupan jemaat. Hal ini merupakan implementasi dari pentingnya penginjilan dan misi dilakukan gereja yang menjadikan misi sebagai ibu dari teologi. ${ }^{22}$ Para pemimpin GBI Gatot Subroto menyatakan tindakan ini memberi dampak besar bagi masyarakat gereja dan umum untuk mengurangi kemiskinan.

Ketiga, service. GBI Gatot Subroto sebagai gereja yang berdoa, gereja yang menyembah, gereja yang bersaksi dan gereja yang melayani (a praying, worshipping, witnessing and serving church) telah banyak memberi warna bagi pelayan gereja-gereja di Indonesia dan dunia. Dalam kegerakan apostolik dan profetiknya maka GBI Gatot Subroto telah menjadi mitra dan memcapai kurang lebih 7.000 PHTGD (Persekutuan Hamba Tuhan Garis Depan) di Indonesia, yang berasal dari hampir $75 \%$ sinode-sinode gereja yang ada di nusantara. Dalam gereja apostolik transformatif doa juga digunakan dalam peperangan rohani. Dalam peperangan rohani, doa digunakan untuk merebut tempat-tempat yang menjadi pijakan musuh. Selama sejarah kekristenan telah menemukan pengaruh- pengaruh kuasa jahat (demonic influences), maka doa yang berkuasa serta menyerang akan menyebabkan Tuhan berperan dan memberikan daerah-daerah tersebut untuk diinjak dan kuasai kembali. Dalam pelayanan misi, khususnya dalam penjangkauan serta penanaman gereja di tempat-tempat yang baru harus dimulai dengan terobosan doa. Oleh karena di tempat-tempat tersebut Iblis telah berpijak melalui penyembahan berhala, darah tertumpah, imoralitas serta kekacauan dan kekerasan hati. ${ }^{23}$ Implementasi ini termasuk bagian dari poin 3, 8, 9, 10.

Keempat, Development of the Poor. Pelayanan transformasi untuk pengentasan kemiskinan dilakukan di banyak rayon GBI Gatsu dengan berbagai Pilot Project sesuai kemampuan tiap rayon. Pengentasan kemiskinan itu tampak dalam hal, antara lain: Pelatihan-pelatihan usaha kecil di berbagai daerah, Pelatihan tenaga kerja entrepreneur, Development program, Pelatihan profesi dan ketenagakerjaan, Pelayanan-pelayanan sosial pendidikan luar sekolah dan kejuruan, Penampungan rumah yatim dan panti jompo, Pelayanan masyarakat terabaikan, Pelayanan kesehatan, Pelayanan bantuan sosial untuk kelompok putus sekolah, Pelayanan kesehatan untuk masyarakat melalui berbagai klinik pengobatan, rumah sakit sederhana, rumah sehat dan penampungan sakit jiwa.

Di sinilah Karya Roh Kudus bagi gereja masa kini tampak melalui karunia pelayanan kenabian dan kerasulan yang semakin nyata. ${ }^{24}$ Pemimpin kerasulan GBI Gatot Subroto dan tim yang ada sejak sebelum terjadinya tsunami Aceh telah memiliki hati dalam pelayanan benevolence, care and compassion (pelayanan kebajikan, kepedulian dan belas kasihan) melalui YKPMI (Yayasan Kasih Peduli Masyarakat Indonesia). YKPMI bergerak dalam TAGANA nasional. Pelayanan terpadu penanganan bencana alam bekerja sama dengan banyak PEMDA, ikut terlibat di dalam penanganan masalah masalah kemiskinan dan bencana di daerah. Tindakan ini termasuk dalam implementasi point keempat.

\footnotetext{
22 John Stott, Christian Mission in The Modern World (Laysister: IVP Books, 1975).

${ }^{23}$ Bob Becke dan Rebecca Sytsema, Commitment to Conquer: Redeeming Your City by Strategic Intercession (Grand Rapids, Michigan: Chosen, 1997).

${ }^{24}$ David Cartledge, The Apostolik Revolution: The Restoration of Apostolik and Prophetic Ministry in The Assemblies of God in Australia (Chester Hill, NSW, Australia: Paraclete InsDtute, 2000).
} 
Kelima, education. GBI Gatot Subroto terpanggil untuk melayani dan mencerdaskan kehidupan bangsa melalui pendidikan formal di tingkat SD, SMP, SMA, College, serta sekolahsekolah teologi. Sekolah-sekolah umum Kristen tersebar di berbagai provinsi dan daerah. Departemen pendidikan GBI Gatot Subroto juga memberikan beasiswa bagi anak dari keluarga tidak mampu dan menyekolahkan mereka sampai ke pendidikan tinggi. PAUD (Pendidikan Anak Usia Dini) juga ada di berbagai rayon yang ada di GBI Gatot Subroto. Di samping pendidikan formal, transformasi di bidang pendidikan juga diberikan dalam bentuk pendidikan informal, yakni dalam bentuk pelatihan-pelatihan berdiploma baik di bidang gerejawi, sosial enterprise dan bakat. Tindakan ini adalah bagian dari implementasi point 4. Menurut narasumber, gereja mengeluarkan dana yang besar untuk pendidikan anak bertujuan menjaga kualitas jemaat dan juga membantu tugas pemerintah dalam memerangi kebodohan dan kemiskinan akibat dari kebodohan.

Keenam, family. GBI Gatsu dan semua rayonnya memiliki program penguatan untuk keluarga. Keluarga adalah pilar yang harus mengalami transformasi. Program kelas pra-nikah dan kelas pasca-nikah serta pelatihan dan seminar secara berkala dilakukan secara intensif baik untuk keluarga muda maupun keluarga senior, parenting dan single parent. Departemen khusus yang membawahi bidang keluarga juga secara aktif melayani konseling untuk pasangan suami istri. Menurut narasumber, dengan memfokuskan keluarga, maka gereja akan sehat dalam pertumbuhan biologis. Sebab jika keluarga sehat, maka gereja akan sehat.

Ketujuh, Government. Banyak pengerja dan aktivis di GBI Gatot Subroto yang terlibat di dalam pemerintahan baik sipil, militer dan juga aktivis-aktivis Lembaga Swadaya Masyarakat (LSM). Juga banyak jemaat yang terlibat langsung dalam politik nasional, melalui krterlibatan dalam partai-partai nasionalis yang ada. Gerakan transformasi di pemerintahan bekerja sama dengan Transformation Connection Indonesia (TCI) menghadirkan pelatihan seminar, temu bicara untuk memberi pemasukan di level Pemerintah Kota (Pemkot), Pemerintah Daerah (Pemda) dan di berbagai bidang transformasi di level nasional. Menurut narasumber, tindakan ini bukan bertujuan untuk mengamankan gereja agar mudah untuk beribadah, melainkan suatu tindakakan tanggung jawab, ketertundukan, dan menggarami bangsa.

\section{Kesimpulan}

Gereja Bethel Indonesia Gatot Subroto sebagai gereja apostolik telah mengimplementasikan value dari gereja yang melakukan transformasi dalam segala bidang kehidupan masyarakat secara umum, dan jemaat secara khusus. Hal ini terlihat dari tujuh bidang yang dikerjakan oleh GBI Gatot Subroto yaitu: art and media production; business and marketplace; service; development of the poor; education; family; dan government. Dari ketujuh bidang yang dikerjakan GBI Gatot Subroto, yang dikerjakan untuk transformasi jemaat lokal adalah yang poin 1-6, sedangkan yang untuk masyarakat secara umum adalah 1-4, 7. Ketujuh tindakan yang dilakukan oleh GBI Gatot Subroto adalah implementasi dari value gereja yang mentransformasi. Hal ini terlihat dari tujuan utamanya adalah untuk melakukan visi utama dari Tuhan, yaitu melaksanakan Amanat Agung dalam Matius 28:19-20. Visi besar inilah yang membuat gereja melaksanakan tindakan-tindakan yang menyentuh seluruh kebutuhan jemaat dan masyarakat. Sebab jika hanya menyentuh bidang rohani, maka akan sulit untuk masuk kepada masyarakat secara luas. Tetapi, dengan menyentuh seluruh bidang kehidupan manusia, maka pengaruh dan dampak dari pelayanan tranformasi dapat dirasakan kepada khalayak banyak. 


\section{Referensi}

Ardhi, FX Wibowo. Arti Gereja. Yogyakarta: Kanisius, 1993.

Barney, Coombs. Apostles Today - Christ's Love-Gift to the Church. England: Sovereign World Ltd, 1996.

Cartledge, David. The Apostolik Revolution: The Restoration of Apostolik and Prophetic Ministry in The Assemblies of God in Australia. Chester Hill, NSW, Australia: Paraclete InsDtute, 2000.

Dalensang, Remelia F. "Menjadi Gereja Yang Transformatif Bagi Kaum Miskin 'Dari Mana Dan Ke Mana Arah Pembangunan Jemaat ?"” 7 (2018): 51-61.

David, Cannistraci. Karunia Rasul: Sebuah Pandangan Alkitabiah Mengenai Jawatan Rasul Dan Bagaimana Tuhan Sedang Menggunakannya Untuk Memberkati Gereja-Nya Dewasa Ini. Jakarta: Nafiri Gabriel, 1997.

Dwiraharjo, Susanto. "Kajian Eksegetikal Amanat Agung Menurut Matius 28 : 18-20.” Jurnal Teologi Gracia Deo 1, no. 2 (2019): 56-73. http://sttbaptisjkt.ac.id/ejournal/index.php/graciadeo.

Gemeren, Willem A Van. Penginterpretasian Kitab Para Nabi. Surabaya: Momentum, 2007.

Grudem, Wayne. The Biblical Foundations on Manhood and Womanhood: The Myth of Mutual Submission As An Interpretation Of Ephesians 5:21. Wheaton, Illinois: Crossway Books, 2002.

Hasiholan, Anggi Maringan. "Studi Komparatif Terhadap Pemahaman Teologi Reformed Dengan Pemahaman Teologi Pentakosta Tentang Natur Manusia.” Pneumata 1, no. 1 (2020): 54-71.

Panamokta, Gerardus Hadian. "Menuju Gereja Terjaring (Networked Church)." Jurnal Teologi 7, no. 1 (2018): 9-30.

Prasetyo, Widi. "Rekrutmen Pelayan Yang Ideal Menurut Kisah Para Rasul 6:3." Kerusso 1, no. 1 (2016): 57-64.

Pulung, Cornelius. "Gereja Yang Satu, Kudus Dan Apostolik Dalam Gereja Katolik." BINUS University (2020): 1-20.

Samuel, Chris Sugden dan Vinay. Mission as Transformation: A Theology of the Whole Gospel. Eugene: Wipf and Stock Publishers, 2009.

Schaff, Philip. History of the Christian Church, Volume I: Apostolic Christianity. A.D. 1-100. USA: Christian Classics Ethereal Library, 1882.

Siahaya, Johannis, and Harls Evan R Siahaan. "Menggagas Hospitalitas Pentakostal: Membaca Ulang Kisah Para Rasul 2: 44-47 Di Masa Pandemi.” DUNAMIS: Jurnal Teologi dan Pendidikan Kristiani 5, no. 2 (2021): 426-439.

Simamora, Ridwan Henry. "Gereja Dan Transformasi Kristen Suatu Tinjauan Kritis Terhadap Misi Gerakan Transformasi.” Missio Ecclesiae 03, no. 04 (2013): 84-109.

Soesilo, Yushak. "Pentakostalisme Dan Aksi Sosial: Analisis Struktural Kisah Para Rasul 2 : 4147.” DUNAMIS: Jurnal Teologi dan Pendidikan Kristiani 2, no. 2 (2018): 136-151. http://sttintheos.ac.id/e-journal/index.php/dunamis/article/view/172/134.

Stott, John. Christian Mission in The Modern World. Laysister: IVP Books, 1975.

Sunarko, Andreas Sese. "Implementasi Cara Hidup Jemaat Mula-Mula Dalam Kisah Para Rasul 2: 41-47 Bagi Pertumbuhan Gereja Masa Kini." KHARISMATA: Jurnal Teologi Pantekosta 2, no. 2 (2020): 127-140.

Sytsema, Bob Becke dan Rebecca. Commitment to Conquer: Redeeming Your City by Strategic Intercession. Grand Rapids, Michigan: Chosen, 1997.

Thomas, John Christopher. Toward a Pentecostal Ecclesiology: The Church and the Fivefold Gospel. Cleveland, Tennessee: CPT Press, n.d.

Tomberlin, Daniel. Encountering God at The Altar, Pentecostal Sacraments. Cleveland, Tennessee: Thomas Nelson, 2015. 
Victor, Choudhrie. Greet the Ekklesia! The Church in Your House. Kindle edi. Power through love, 2012.

Wagner, Peter. Changing Church: How God Is Leading His Church into The Future. California: Ventura, 2014.

Widjaja, Fransiskus Irwan, Daniel Ginting, and Sabar Manahan Hutagalung. "Teologi Misi Sebagai Teologi Amanat Agung.” THRONOS: Jurnal Teologi Kristen 1, no. 1 (2019): 1724. 